\title{
КРИТЕРИИ СФОРМИРОВАННОСТИ КОМПОНЕНТОВ ПРОФЕССИОНАЛЬНОГО САМОСОЗНАНИЯ СТУДЕНТОВ
}

\author{
Эннс E. $A$.
}

Пятигорский Государственный Университет, г. Пятигорск, Ставропольский край, Российская Федерация

В статье раскрываются теоретические подходы к исследованию формирования профессионального самосознания студентов вуза. Представлена структура профессионального самосознания. Обосновывается система критериев сформированности компонентов профессионального самосознания.

Ключевые слова: профессиональное самосознание; критерии сформированности компонентов профессионального самосознания; профессионализачия.

\section{CRITERIA FOR THE FORMATION OF COMPONENTS OF PROFESSIONAL SELF-CONSCIOUSNESS OF STUDENTS}

\section{Enns E. A.}

Pyatigorsk State University, Pyatigorsk, Stavropol region, Russian Federation

The article reveals theoretical approaches to the study of the formation of professional self-consciousness of tertiary students. The structure of professional self-consciousness has been presented. The set of criteria of the formation of professional self-consciousness is substantiated.

Keywords: professional self-consciousness; criteria of formedness of professional self-consciousness; professional development. 
В настоящее время вузы нацелены на выпуск готовых к полной профессиональной самореализации, зрелых, конкурентоспособных выпускников. Системная целенаправленная работа по управлению процессом профессионального развития и становления, должна быть направлена на формирование обладающего особой интегрирующей и регулирующей профессиональную деятельность структуры: профессионального самосознания. Поэтому, важными актуальными задачами современной педагогической психологии в настоящее время являются задачи формирования профессионального самосознания студентов вуза, выявления механизмов, закономерностей, условий осуществления данного процесса, создание реестра технологий, которые способствуют развитию профессионального самосознания студентов вуза.

В отечественной психологии развивается подход, согласно которому развитие совершается в неразрывной внутренней связи с обучением, в ходе его поступательного движения (Л.С. Выготский) [1]. Это положение относится и к процессу формирования структур профессионального самосознания, в результате осуществления ведущей учебно-профессиональной деятельности для данного возрастного периода. Выступая инструментом самодетерминации профессиональной активности личности профессиональное самосознание системно связано и с личностным развитием и с конструированием жизненного плана личности.

Стихийное, случайное, дисгармоничное становление профессионального самосознания продляет сроки адаптации выпускника вуза в избранной профессии, тормозит профессиональное становление личности, снижает конкурентоспособность.

Являясь высшим уровенем развития профессионального сознания профессиональное самосознание рассматривается как интегральное личностное образование, формирующееся в профессиональной среде и в процессе осуществления учебно-профессиональной и профессиональной деятельности.

Рассмотрим ключевые компоненты модели профессионального самосознания. Выделяют когнитивный, аффективный, поведенче- 
ский компоненты, реализуемые через соответственно «я-понимание», «я-отношение», «я-поведение»). Данная трехкомпонентная структура отражает соответствие профессионального самосознания со структурой самосознания личности (А.К. Маркова, В.В. Столин) $[2,3]$.

Высокий уровень развития когнитивного компонента профессионального самосознания соответствует наличию развитых представлений о своих профессиональных качествах, глубоких знаний о сути и содержании своей профессиональной деятельности, характеризуется интегрированностью образа я-профессионал и я-концепциии личности. Высокому уровню развития аффективного компонента соответствует адекватная оценка себя как профессионала, положительное профессиональное самоотношение. Поведенческий компонент представлен наличием ярко выраженного мотива к самореализации в профессии, к самоактуализации, в стремлении к профессиональному саморазвитию.

Противоречие между достигнутыми и желаемыми я-образами, которое интериоризируется и актуализируется личностью в процессе профессионально-учебной деятельности является движущей силой развития профессионального самосознания. Это образование динамично. Развитие компонентов претерпевают изменения и достигают в своем развитии определенных уровней, преобразуясь из разрозненного диффузного состояния в состояние структурированности и оптимальности.

Рассмотрим систему критериев сформированности компонентов профессионального самосознания.

Когнитивный компонент. Низкий уровень: несформированность представлений и знаний о профессиональных процессах и технологиях, сути выполняемых трудовых функций, отсутствие представлений о своих профессиональных качествах, представлений о профессиональных отношениях, представлений о перспективах профессионального развития, образ я-профессионал диффузен, не связан с я-концепцией, не выражен интерес к самопознанию, самопониманию, саморазвитию в профессиональной деятельности. Средний уровень: присутствие разрозненных представлений и знаний о профессиональных процессах и технологиях, сути выполняе- 
мых трудовых функций, представлений о своих профессиональных качествах, представлений о профессиональных отношениях, представлений о перспективах профессионального развития, образ я-профессионал слабо с я-концепцией, слабо выражен интерес к самопознанию, самопониманию, саморазвитию в профессиональной деятельности. Высокий уровень: Наличие реалистичных представлений и знаний о профессиональных процессах и технологиях, сути выполняемых трудовых функций, представлений о своих профессиональных качествах, представлений о профессиональных отношениях, представлений о перспективах профессионального развития, образ я-профессионал интегрирован с я-концепцией, выражен интерес к самопознанию, самопониманию, саморазвитию в профессиональной деятельности.

Аффективный компонент. Низкий уровень: отсутствует или проявляется неоднородно положительное отношение к себе, к субъектам профессионального взаимодействия, к профессиональной деятельности, неадекватная оценка себя как специалиста с точки зрения установленных профессиональных эталонов, искаженное понимание своих профессиональных качеств, потенциала, возможностей профессионального роста, своего места в профессиональном сообществе и профессиональной среде. Средний уровень: проявляется неоднородно положительное отношение к себе, к субъектам профессионального взаимодействия, к профессиональной деятельности, неустойчивая оценка себя как специалиста с точки зрения установленных профессиональных эталонов, своих профессиональных качеств, потенциала, возможностей профессионального роста, своего места в профессиональном сообществе и профессиональной среде. Высокий уровень: положительное отношение к себе, к субъектам профессионального взаимодействия, к профессиональной деятельности, адекватная самооценка себя как специалиста с точки зрения установленных профессиональных эталонов, своих профессиональных качеств, потенциала, возможностей профессионального роста, своего места в профессиональном сообществе и профессиональной среде. 
Поведенческий компонент. Низкий уровень: трудности осуществления рефлексивных действий в профессиональной деятельности, не сформирована произвольность в саморегуляции трудовой деятельности, не выражены самоактуализирующие в труде действия, стремление к саморазвитию. Средний уровень: ограничена способность осуществления рефлексивных действий в профессиональной деятельности, слабо сформирована произвольность в саморегуляции трудовой деятельности, слабо выражены самоактуализирующие в труде действия, стремление к саморазвитию. Высокий уровень: выраженная способность осуществления рефлексивных действий в профессиональной деятельности, хорошо развита произвольность в саморегуляции трудовой деятельности, стремление к саморазвитию, самосовершенствованию, самоактуализации.

Результатом представляется самоопределение студента в координатах профессионального развития, инструменты самоорганизации в профессиональной трудовой деятельности, осознание новых конструктов личности, профессиональных перспектив, возможностей целеполагания.

\section{Список литературы}

1. Выготский Л.С. Избранные психологические исследования / Л.С. Выготский. М., 1956. 55 с.

2. Маркова А.К. Психология профессионализма. М., 1996. 309 с.

3. Столин В.В. Самосознание личности. М.: МГУ, 1983 г.

4. Эннс Е.А. Психолого-педагогические условия развития профессионального самосознания студентов вуза / Е.А. Эннс // В мире научных открытий. 2015. № 9-3 (69). С. 1031-1040.

5. Эннс Е.А. Формирование профессионального самосознания студентов вуза / Е.А. Эннс // В мире научных открытий. 2015. № 11-1 (71). C. $773-781$.

6. Эннс Е.А. Профессиональное самосознание как регулятор профессионального развития / Е.А. Эннс // Университетские чтения - 2015. Материалы научно-методических чтений ПГЛУ. 2015. C. $163-166$. 
7. Berezhnova O.V., Piliugina E.I., Poklonskaya V.D., Enns E.A., Serdiukova E.F. Theoretical grounds for the development of professional selfconsciousness of students in the information-oriented society // Advances in Intelligent Systems and Computing. 2019. T. 726. C. 1060-1067.

\section{References}

1. Vygotskiy L.S. Izbrannye psikhologicheskie issledovaniya/L.S. Vygotskiy. M., 1956. $55 \mathrm{~s}$.

2. Markova A.K. Psikhologiya professionalizma. M., 1996. 309 s.

3. Stolin V.V. Samosoznanie lichnosti. M.: MGU, 1983 g.

4. Enns E.A. Psikhologo-pedagogicheskie usloviya razvitiya professional'nogo samosoznaniya studentov vuza / E.A. Enns // V mire nauchnykh otkrytiy. 2015. № 9-3 (69). S. 1031-1040.

5. Enns E.A. Formirovanie professional'nogo samosoznaniya studentov vuza / E.A. Enns // V mire nauchnykh otkrytiy. 2015. № 11-1 (71). S. 773-781.

6. Enns E.A. Professional'noe samosoznanie kak regulyator professional'nogo razvitiya /E.A. Enns // Universitetskie chteniya - 2015. Materialy nauchno-metodicheskikh chteniy PGLU. 2015. S. 163-166.

7. Berezhnova O.V., Piliugina E.I., Poklonskaya V.D., Enns E.A., Serdiukova E.F. Theoretical grounds for the development of professional self-consciousness of students in the information-oriented society // Advances in Intelligent Systems and Computing. 2019. T. 726. S. 1060-1067. 